\section{White house conference packs a mighty punch}

\author{
by Patricia A. Wand \\ Chair, ACRL Task Force on WHCLIS
}

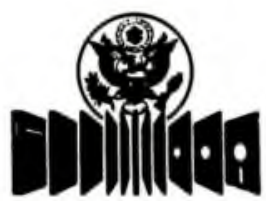

The White House Conference ON
LibraRY AND INFORMATION SERVICES

\section{Delegates represent varied perspectives}

Approximately 650 delegates will be responsible for reviewing issues and formulating resolutions during the upcoming White House Conference.

Jean Curtis, Executive Director of the Conference, noted recently that the delegation accurately mirrors the residents in $\mathbf{5 0}$ states, the District of Columbia, six U.S. territories, native Americans and the Federal Library Community. "The Conference delegates represent a diverse population in terms of geography, professions and socio-economic backgrounds. This provides balance and credibility to the outcome of the Conference."

One hundred fifty-nine delegates are library and information professionals. They work in various types of libraries: $31 \%$ in public libraries, $20 \%$ in school library media centers, and $18 \%$ ( 29 delegates) work in academic libraries. Besides the 22 academic librarian delegates cited in previous issues of C\&RL News, two more have notified this author of their selection: Puerto Rico: Haydee Munos-Sola, University of Puerto Rico, Rio Piedras Campus; Luisa Vigo-Cepeda, University of Puerto Rico, Rio Piedras Campus.

Along with librarians and information specialists there are delegates who are library trustees and supporters, government officials, and the general public. Women comprise $59 \%$ of the total group. Nearly $60 \%$ of the delegates have degrees beyond the four-year baccalaureate. Over half of the delegates who are government officials are elected members of local governments - state, city, or county. The remainder are employees of local or federal governments.

\section{Conference schedule full}

Planners of the White House Conference on Library and Information Services, July 9-13, 1991, packed a tight schedule into the four days and expect full participation from delegates. All dele- gates will deliberate issues in topic group meetings and then draft recommendations that will be finalized by the Conference Recommendations Committee. The original 2,500 issues have already been consolidated and summarized to some extent but delegates are still faced with many hours of review and discussion. Topic group meetings are sandwiched between a full agenda of keynote speakers, lectures, plenary sessions, and receptions.

\section{Experts address conference}

Three experienced people were named chairman, co-chairman and vice-chairman of the White House Conference. Charles Reid, chairman, is a life-long user and supporter of libraries who is currently chairman of the National Commission on Libraries and Information Science. Richard Akeroyd, co-chairman, is the state librarian of Connecticut and served as a staff member for the first White House Conference in 1979. Joseph Fitzsimmons, vice-chairman, has been president and CEO of University Microfilms International for 15 years.

All three of these leaders will address delegates as will a host of other notables, including possibly President George Bush. Keynote and other speakers are Congressman Major Owens (D-NY); James Billington, Librarian of Congress; Mary Futrell, former president, National Education Association; William Esrey, president, United Telecommunications; and Deborah Kaplan, Association Director for Public Education, World Institute on Disability.

The topic of a special session, "The Great Debate," is the future of library and information services. Arthur Miller, Harvard University Law School, will moderate and panelists are: Clement Bezold, executive director, Institute for Alternative Futures; Robert Houk, U.S. Public Printer; Charles McClure, professor, Syracuse University; Anthony Oetinger, professor, Harvard University; Amy Owen, state librarian, Utah; Phyllis Steckler, president, Orynx Press; Charles Robinson, direc- 
tor, Baltimore County Public Library; Jack Simpson, CEO, Mead Data Central; and Don Wilson, archivist of the United States.

It is clear that the White House Conference on Library and Information Services 1991 will provide leadership and vision for all players in the information age.
Publications and additional information about the Conference may be requested from the office of the White House Conference on Library and Information Services 1991, 1111 8th Street, N.W., Suite 302, Washington D.C. 20036; phone (202) 254-5100.

\section{Bloomfield College hosts "The Multicultural Library: The Way of the Future"}

On May 3, 1991, Bloomfield College, Bloomfield, New Jersey, along with the Essex Hudson Regional Library Cooperative, sponsored a forum entitled "The Multicultural Library: The Way of the Future." Keynote speakers were Bloomfield College president John $\mathrm{F}$. Noonan and Alex Boyd, director of the

Newark Public Library. The program featured a panel discussion with Bloomfield College library director Danilo $\mathbf{H}$. Figueredo; Kathleen Johnson, assistant general counsel, and Stephen Gargulinski, educational media supervisor, of the Jersey City Public Schools; and Ramya Subramanian, librarian of the Non-English

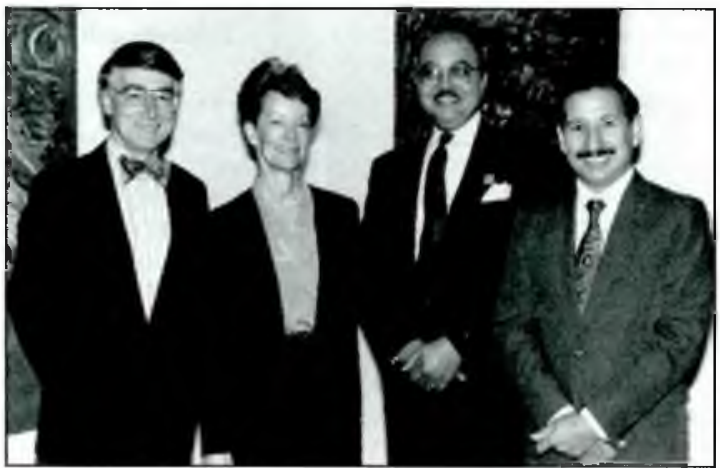

John F. Noonan, Joanne R. Euster, Alex Boyd, and Danilo $H$. Figueredo
Ultimately, there must be corresponding programs, resources, and services in a library for each of the cultural components of the community a library serves.

Founded in 1868 and located one mile from Newark, Bloomfield has a student body of 1,700 , representing 51 different nationalities. When Noonan first arrived on campus in 1987 , he revised the institution's mission s t a t e m e n t, which now states that the college is to be "preparing students to function at the peak of their potential in a multiracial, multicultural society." Since then each course in the curriculum has been brought into line with this new mission statement. In 1988, the college was awar-ded one of four Excellence Initiative Grants from the New Jersey Department of Higher Education.

For Noonan, the library is a vital link in his plans to implement the new mission, using the analogy that libraries are "a mirror of society as well as an image in front of the mirror." Figueredo adds that "Libraries are no longer passive places. They are, and rightly should be, participants in the process of social change. They are and should be offering programs, cultural events, and collections pertaining to specific ethnic groups in the groups' respective languages, for example." 